\title{
CHILD VULNERABILITY AND WELL-BEING AMONG FARMER FAMILIES
}

\author{
Danisya Primasari* \\ Department of Family and Consumer Sciences, \\ Faculty of Human Ecology, \\ Bogor Agricultural University \\ Herien Puspitawati \\ Department of Family and Consumer Sciences, \\ Faculty of Human Ecology, \\ Bogor Agricultural University \\ *Corresponding author: danisya.ajja@gmail.com
}

\begin{abstract}
This research aimed to identify vulnerability and well-being of children in a family of farmers, identify the typology of vulnerability and well-being of children in the family of farmers, and analyze the relationship between family characteristics, characteristics of children with the vulnerability and well-being of children. The population in this research is family farmers who have children of 4 and 5th grade who reside in the village Sindangjaya, District Cipanas, Cianjur with a sample of 35 children. Sampling was conducted using probability sampling method with random sampling techniques. The results showed that the internal susceptibility to family farmers is low, relatively low external vulnerability, and low well-being. Typology vulnerability of children and the well-being of children in a family of farmers included in Type 1 and Type 4. There was a significant negative correlation between family size and order of the child with the child's welfare, but there was no significant relationship between the characteristics of families and children with children's vulnerability.
\end{abstract}

Keywords: internal vulnerability of children, the external vulnerability of children, child welfare, family farmers. 


\section{INTRODUCTION}

Child Vulnerability refers to developmental needs and the importance of protecting the physical health of children (Raphael, et al. 2006). The population of susceptible individuals needs legal assistance, social support and health services. The number of susceptible children may increase when children are in complex issues, such as health problems (chronic, disability), living with adults who are sick, and children becoming head of the family or breadwinner (Andrews, et al. 2006). Unstable life situations related to susceptibility, for example living in the street, surviving in the conflict situation, assaulting, or armed child labor. Muriuki \& Moss (2016) revealed that the extent and type of vulnerabilities faced by children can be influenced by the characteristics of risk and stress faced. External vulnerability means to the risk, shocks and stress, internal vulnerability refers to a lack of resources to cope with stress. External vulnerability factors related to the bio-physical and socio-economic, while the internal vulnerabilities associated with the lack of strength and inability to act or plan the future.

The percentage of poor people in the rural areas of West Java per September 2014, according to the The Central Statistics Agency (2016) amounted to 10.88 percent of the household whose main income was of agriculture - 51.67 percent. Children can become vulnerable because children have very limited access to basic needs such as education, health, and they do not obtain good sanitation, and lack of attention compassion, love, guidance and support from the surrounding environment (Skinner et al., 2004). Poverty will cause problems in children, one of which is the vulnerability of children. Families and children who are vulnerable have limited resources such as education, employment, and the obstacles to obtain other social services (Zambrana \& Dorrington, 1998). Vulnerability seen as a cause of poverty is the reason why the poor remains poor, or as a result of poverty (Permana, 2008). Engle, et al. (1996) states that the challenges faced by kids today is the changing times, including increasing urbanization, political violence, child abuse, changes in family forms, and in some areas, they have experienced a decrease in food supplies. The vulnerability of children has risen markedly as a result of emotional tension and less ability to adapt socially (Tembong, 2006). Economic limitation and knowledge of parents in rural areas in providing guidance and oversight on his son make children drop out of school and this has forced them to meet their own need. Therefore, children help their family to make a living by working around the neighborhood or even outside of the city (Anshor \& Ghalib, 2010).

Poverty alleviation is one of the development priorities of the Indonesian Government that aims to reduce the poverty rate to 8 until 10 percent by 2014 (UNICEF Indonesia in 2013). One of the Millennium Development Goals (MDGs) is seek to build the lives and women and children wellbeing to be better, particularly through increasing life expectancy, reducing poverty, and improving health, nutrition and access to education. According to Law No. 23 of 2002 Article 8 states about protection for children that every child has the right to obtain medical care and social security in accordance with physical, mental, spiritual, and social needs. The rights of children are a part of human rights which must be guaranteed, protected and fulfilled by parents, families, communities, governments, and the state. According to Law No. 4 of 1979, the Child Welfare is 
an order of life and livelihood of children to ensure the growth and development with a reasonable, well spiritually, physically, and socially.

Subjective well-being is an important index to measure the mental health and children's quality of life (Peterson et al., 2014). National legislation, both Act No. 4 of 1979 about Child Welfare and Law 23 of 2002 about Child Protection, has stated the importance of children care by their parents and families (Social Affairs, 2011). Children well-being require special attention, first as a child welfare issue not only affects the present moment, but will have an impact on the future of children. Second, because children are one of the groups most affected by poverty, and the third because there are lack of direct information about the child's life (Fernandes et al., 2010). At primary school age, the child will experience an important stage in the formation of his personality. Hurlock (1980) suggested the primary school age children is an important period for the conditions that lead to future happiness in this period and will continue to create happiness in the future.

This study aims to identify children vulnerabilities and well-being in a farming family, identify the typology of vulnerability and child well-being in a farming family, and analyze the relationship between family characteristics, characteristics of children with the vulnerability of children and child well-being. Therefore, researchers are interested to see how the vulnerability and child wellbeing in the family farmer in the village Sindangjaya, Cipanas District, Cianjur Regency, West Java.

\section{RESEARCH METHODS}

The design of this study was cross sectional study using interviews assisted by using a questionnaire. The research location is in the village of Sindangjaya, Cipanas District, Cianjur Regency selected intentionally (purposive). The reason to select the locations was that the majority of residents of the area is horticulture or ornamental plant farmers.

The population in this study was a family with a husband or wife or both were working as farmers who reside in the village of Sindangjaya. Farmers in this case are farmers who own land gardens or fields, sharecroppers or tenant, as well as farm laborers. Sampling used non-probability sampling method with purposive technique, the method by way of example chosen by students grades 4-5 elementary school parents whose work status is farmers, both father and mother who take care of their work or paddy plantation land owned or owned by other daily. Respondents in this study were children who were selected using probability sampling method with simple random sampling technique which was subsequently elected as many as 35 children.

The data in this study consisted of three main variables, namely the characteristics, the vulnerability of children and child welfare. The variable characteristics of children were assessed from age (years), gender (male and female), and birth order. Variables were assessed by family characteristics of the age of the father and mother (years), duration of education father and mother (years), father and mother work, income and family expenses, large families, as well as family assets. 
Children's vulnerability was measured using the concept of Skinner et al (2004) and Bannet (2012). Number of statement items as much as 19 items, vulnerability of children is measured by the two sides, namely internal and external. Internal vulnerability of children used a questionnaire with 19 questions of item numbers. The number of questions was 19 items, and the validation test was done with 17 items filled with valid questions. Each statement is provided 4answers with a score of 1 to answer "never", a score of 2 to answer "sometimes", with a score 3 to answer "quite often", and a score of 4 to answer "often". External vulnerability of children used a questionnaire with 13 questions, and the validation test was done with the number 8 items with valid questions. Each question provided two answers with a score of 0 for "No" and 1 for "Yes". Vulnerability of children was taken from two sides, namely internal and external which had been tested its validity and reliability with Cronbach's alpha for internal vulnerability of children of 0.869 , while the external vulnerability of children at 0.429 . Scores obtained will be transformed into the form of an index and then they were grouped into two categories, namely low and high. Variable contents for internal vulnerability of children ranged from -0.054 to 0.826 and for the variable content of external vulnerability of children ranged up to $0.631-0.084$.

Child welfare was obtained using a questionnaire Puspitawati (2012) modified from Campbell, et al. (1976). Total statement was 11 items, and then the validation of test content was performed with the number of 10 items of a valid question. Each statement will be illustrated by a number from one to seven. The lower the score of the statement (approaching one), the more negative feeling you get. Conversely, the greater the score of the statement, the more positive feeling you get. Thus, this obtained the minimum and maximum value of 77 . The value of Cronbach's alpha of child welfare is 0.719 . Variable contents for child welfare ranged from 0.068 to 0.681 .

Analysis of the data used was descriptive and inferential analysis. Descriptive analysis included the average, standard deviation, minimum value and a maximum value used to describe the characteristics of the family, child characteristics, vulnerability and child welfare. Analysis inference used Pearson correlation test to find out the relationship among family characteristics, child characteristics, the vulnerability of children and child welfare.

\section{RESULT}

\section{Characteristics of Families and Children}

Characteristics of children in this study were students of $4^{\text {th }}$ and $5^{\text {th }}$ grade in Sindanglaya and Sindangjaya Public Elementary Schools, Suryakencana Village, Cipanas District. Characteristics of children in the study include gender, age, and birth order of the child. Number of the child based on gender in this research is dominated by girls (51.4\%) than boys (48.6\%) with an average age ranging from 11 years. A total of 25.7 percent of children is born in second order with the order birth average at third order. The mean of father age is 46 years with an age range 33 to 60 years. Meanwhile, the average maternal age was 39 years with an age range of 28 to 56 years. The father age belongs to middle age group, 
and maternal age belogs to early adulthood group. This shows that farming done by families was implemented by productive aged farmers.

The education level of the father and mother will affect the ways and mindset to be able to meet the needs of the uncertain socio-economic conditions (Simanjuntak, 2010). Based on the results of analysis, this shows that the average length of father education is 6 years old, with long range education of 0 to 12 years. In addition, the average length of mother education is 5 years old with a range of mother's education of 0 to 6 years. The low level of public education can cause the lower levels of well-being. Higher level of education is a mean to achieve a higher quality of life and make it easier for someone to earn a decent living and provide sufficient income families (Simanjuntak, 2010b).

All of fathers in this research have main livelihood as farmers. Three of the seven mothers do not work or as a housewife. According to Soeharjo and Patong in Gustiana (2012) there are four types of farmers' status in farming, namely: 1) owners are farmers who own land, the land can be done alone or hire someone else; 2) renters are farmers who rent land from another person to serve as agriculture; 3) Tenants are farmers managing the land owned by another person with the income generated by agricultural use system for results; 4) Laborers are farmers who work on land owned by another person with the wage system, that are owners, renters, tenants, and laborers.

According to the sampling criteria, of the seven family farmers, four owns the plantations alone or as the owners of the garden, the farmers who own the land to be developed as a farm, and the rest $(20.0 \%)$ as a laborer. Half of the sample families $(48.6 \%$ ) included in the category of medium family (5-6 people) with an average family size of 6 people. The fewest number of families in this study was three people while the most number of families was 9 people.

According Sumarwan (2002), income is the remuneration received by a person from the work he has done to earn a living. Family income is the sum of all income obtained from each family member. This revenue comes from the father, mother, and other family members either from the main job (farmers) or from any other job. The results showed almost the whole family (91.4\%) had a per capita income of less than Rp500,000 with an average income per capita of Rp231.000.

Expenditure can be used as an indicator of family income that can describe the financial condition of the family (Sumarwan, 2002). Condition of family expenses that outweigh the income is a natural thing because income is one of the family resources that can be used to meet the needs of families, for example borrowing or having debt. The analysis test showed that most family spend their money on everyday needs ranging from less than Rp500,000 with an average families expenditure per capita per month of Rp248.554.

One of the causes of inprosperous family is low income received by family. Income farm workers in July 2014 amounted to Rp44.569 per day (The Central Statistics Agency 2014). Thus, income farm workers for one month around Rp1.337.070, so per capita income of farm workers with the condition as a large family (six people) amounted to Rp222.845. When compared with the Poverty Line (PL) of The Central Statistics Agency for rural areas in Indonesia in September 2013, which amounted to Rp275.779 per capita per month, we can say that the family is in impoverished condition. The analysis showed that the average 
farmer family income per capita per month is less than the family expenditure per capita. This is in line with Simanjuntak (2010b) who stated that to meet the needs of families and cover the shortfall needs of the families, farmer families will borrow and get assistance from relatives or government.

Asset is one of the resources or property owned by a family that can be cash or non cash form (Hartoyo \& Aniri, 2010). In this study, the assets are divided into five groups: home, garden or paddy fields, small livestock, large livestock and motorcycle. Therefore, families who have more assets tend to be more prosperous when compared with families who have limited assets (Iskandar et al., 2010). The house is an important necessity for every family (Simanjuntak, 2010b). A permanent home or one's own can be a reunification for a child who has been separated from his family (Torrico, 2009). Based on the ownership of assets, it is known that most families $(85.7 \%)$ had a house with a family-owned ownership status and as much as $14.3 \%$ of families was living in extended family or contracting. More than half of respondents $(62.9 \%)$ had a garden or paddy fields. The land was normally planted with pokcoi, leeks, carrots, turnips, and ornamental pieces vegetables which can then be sold to a middleman (middlemen farmers). About three-quarters of respondents (74.3\%) and the majority of respondents $(97.1 \%)$ didn't have a small livestock such as chickens, ducks, goats and cattle or big like a cow. A total of $(60.0 \%)$ of respondents had a personal vehicle such as a motorcycle because the motorcycle prices can already be reached by the respondents. Motorcycle was used by the respondent to access the needs of agriculture and other purposes.

\section{Vulnerability of Children}

The vulnerability of children is a term used to describe a group of children because of the circumstances, conditions and culture as well as the structure of the pressure that can cause not or does not fulfill the rights of children, and often infringed upon (Suyanto, 2010). Vulnerability of children was categorized into internal vulnerability (social and emotional) and external vulnerability (family and neighborhood). Internal vulnerability of children was seen by two-dimensionalemotional and social. Emotion is one factor that can create a feeling of vulnerability which is not good if this can not be managed well (Ehring et al., 2010). The analysis result showed that the highest internal vulnerability in a farmer's son is an average dimension associated with the children emotional vulnerability (31.71). That means that children are not able to regulate emotional behavior. This can be seen from the quite low emotional indicators met by children.

Internal social vulnerability is a factor that can lead to vulnerability due to the emergence of inequality among individuals that can cause hurt responses to each other or drop to each other (Cutter et al., 2003). The analysis showed that the social vulnerability of children was in the low category (91.4), this indicates that the majority of children do not do anything that could harm another person such as fight with friend, hit or attack others, and sit on the roadside to interfere other people.

Internal vulnerability variable of children shows that over half of the children approached the vulnerability internally $(51.4 \%)$, this indicates that the 
child has not been able to meet the personal needs that exist in the psychological dimentions, which is felt by children and disease ever felt during the last six months. External variables in Table 1 show that most children do not experience the vulnerability. This shows that the family is able to meet the basic needs of children such as the need of meal regularly in two or three times a day and can buy children's clothing once a year in minimum.

Table 1 Distribution of variables based on internal and external vulnerability of children

\begin{tabular}{lcccc}
\hline \multirow{2}{*}{ Category } & \multicolumn{4}{c}{ Dimension } \\
\cline { 2 - 5 } & \multicolumn{2}{c}{ Internal Vulnerability } & \multicolumn{2}{c}{ External Vulnerability } \\
\cline { 2 - 5 } & Social & Emotion & Family & Environment \\
\hline Low $(\leq 75,0)$ & 91,4 & 97,1 & 91,4 & 88,6 \\
High $(>75,0)$ & 8,6 & 2,9 & 8,6 & 11,4 \\
\hline Min-Max $(0-100)$ & $0-100$ & $0-75$ & $0-100$ & $30-90$ \\
Mean \pm SD & $19,63 \pm 28,72$ & $31,71 \pm 21,49$ & $43.46 \pm 29,87$ & $56,57 \pm 15,71$ \\
\hline
\end{tabular}

External vulnerability of children seen by two dimensions: the family and the environment. The analysis showed that the highest external vulnerability in children of farmers is the average dimension associated with a child's environment (56.57). This shows that there is a neighborhood farmer's son that can be harmful for the condition of teenagers who do not continue higher education. Early marriage, teens who are extravagant, and the lack of jobs so that cause many of unemployed around the neighborhood children. The neighborhood children that affect children's vulnerability according to Skinner et al. (2004), is an unsafe environment as less viable settlement, the number of crime, and the lack of adequate facilities as a child, such as educational facilities and children's playground. Then the results of analyzes related to the family indicate that the external vulnerability of children belongs the low category (91.4\%). This shows that the vulnerability of children who come from families do not make the condition of child dangerous. The quality of the relationship between parents and children is an important factor for development of children and adolescents. According to Wong et al. (2009), close relationship between parents and children will increase the child's feelings of support and sense of security, and conflict among generations can be reduced.

\section{Child Welfare}

Child welfare is an order of life and livelihood of children to ensure the reasonable growth and development spiritually, physically, and socially well (Act No. 4 of 1979). Child welfare can be seen from feeling happy or satisfied perceived by the child to the child's life related to psychological, economic, and social condition. The children in this study can be said to be prosperous children because they tend to have good self confidence, enjoy life, and feel useful for families and others. They have many friends, independent, energetic, a good chance, feel satisfied and happy, economic needs of children fulfilled. Moreover, children have achievement in school. Children said to be inprosperous children are they who feel themselves inferior (inferior), cannot enjoy life, feel useless, feel lonely and always troublesome, despair, do not have many choices or let go, do 
not feel satisfied and happy, have difficulties in terms of economy and problems in school. Indicators of child welfare social dimension shows that children tend to do well in school. This is in line with research Statham \& Chase (2010) who states that learning is closely related to child welfare. Learning and wellbeing can show changes from childhood to adolescence.

Economic and social dimensions have the highest average. When viewed as a whole, it is an indicator of the economic difficulties in the economic dimension which has the average score of 4.74 , meaning that children whose families experience economic difficulties. This shows that the welfare of the family in terms of the economy tend to be fairly good, according to the statement's Nadiya (2013) stated that a good family welfare will improve the welfare of children as well. On the psychological dimension, the highest average indicator of children is that children have hope and encouragement which is quite good. The lowest average in the psychological dimension is on indicators of child feeeling himself unhappy and do not have many choices or tend to surrender to the circumstances. This indicates that the psychological wellbeing of children can be influenced by the quality of parenting. According to Thompson et al. (2007) it is suggested that family factors play an important role to determine the child's psychology. This can be seen from the height of family social support, low pressure exerted family, and high warmth created in the family. In addition, the child does not feel the happiness and tend to surrender, in this study, it was also found that children tended to be insecure and lonely.

According to Moore et al. (2008) well-being of children can mean that a child who has had the status of individual biological (healthy lifestyle and overall health as well as the function), the psychological health of the individual (how people think about their own situation and how they get along in a social environment, including the ability to cope with the situation free from the problems that exist), social health (referring to basic skills in participating in constructive activities, as well as the ability to connect emotionally with family, friends, and the environment), and education or intellectual (skills associated with a person's ability to learn, remember, to apply cognitive skills and get involved with the school) good.

Table 2 Distribution of variables based on subjective well-being of children

\begin{tabular}{lccc}
\hline \multirow{2}{*}{ Category } & \multicolumn{3}{c}{ Dimension } \\
\cline { 2 - 4 } & Psychology & Economy & Social \\
\hline Low $(\leq 75,0)$ & 65,7 & 48,6 & 48,6 \\
High $(>75,0)$ & 34,3 & 51,4 & 51,4 \\
\hline Min-Max $(0-100)$ & $29-100$ & $0-100$ & $0-100$ \\
Mean \pm SD & $66,57 \pm 18,96$ & $62,11 \pm 36,20$ & $68,37 \pm 34,09$ \\
\hline
\end{tabular}

Table 2 shows that the subjective well-being of children in psychological dimensions included in the low category $(65.7 \%)$, whereas in the economic and social dimensions of subjective well-being of children, this tends to be high $(51.4 \%)$. This suggests that the children of farmers tend not to feel the happiness and satisfaction on themselves. There are quite few numbers of children who are in a psychological dimension to the lower categories because there are some indicators that cannot be met by the child, so the acquisition of well-being scores 
is low. Children's indicators do not have many options and are not happy to have the lowest average value score, which means that the child feels that they do not have many choices and suffer so that children are not able to express the feelings felt. This is caused by lack of children exposure to parents so that children have difficulty in expressing unfavorable feelings that he was experiencing.

In the variable subjective well-being of children, five of the seven children state that a child has not been prosperous. This indicates that the child was not yet to feel the happiness and satisfaction with what is being experienced by children such as relationships with parents, siblings, friends, hygiene and safety in the home and school environment.

\section{Typology of Children Vulnerability and Child Welfare}

Typology of children vulnerability and welfare in this study seen by the distribution of vulnerability categories of children with subjective well-being of children, namely the high vulnerability of children and the low vulnerability of children with the high child welfare and the low child welfare differentiated into Type 1, Type 2, Type 3, and Type 4. Fourth typology is modified from a model typology T-Double ABCX of family adjustment and adaptation by McCubbin and McCubbin (1987) in Farhood (2004). Type model of vulnerability of children and child welfare will be achieved through two levels (low and high) between the dimensions of vulnerability and the dimensions of child welfare. Dimension of child vulnerability is defined as the unfulfilled basic need condition of children such as physical, emotional, social, and environmental development of the interaction between children in the family and society (Skinner et al., 2004; Bannett, 2012). Meanwhile, subjective well-being of children is defined as a condition of the child's level of satisfaction to herself psychologically, economically and socially based perception (subjective).

Typology vulnerability of children in this study is seen by the distribution of child vulnerability categories with the existing child welfare on farm families, namely the vulnerability of children which is low and the high vulnerability of children which is high and low child welfare. Typology vulnerability of children and the welfare of the children in this study are distinguished into four types, namely: 1) Type 1, is a type of children's vulnerability which is currently low, while the high child welfare means that the child is able to cope problems, or children are able to perceive a problem as a very tough and they do not interfere the pleasure of a child and is satisfied and happy with the circumstances surrounding the child or children; 2) Type 2, the current type of vulnerability of children and higher child welfare can be interpreted even if the child has a problem against him, but the child still feel the happiness and satisfaction maintained; 3) Type 3, it is a type of children's vulnerability when it is high while child welfare is low. This means that children have the problems that can not be handled so that children feel dissatisfied and unhappy with their situation; 4) Type 4 , the current type of vulnerability of children and the welfare of children are low, meaning that the child is able to overcome the existing problems but children may not feel the happiness and joy to the condition itself and the environment around the child. Distribution typology of children vulnerability and welfare can be seen in Table 3. The result showed that more than half of the children in the typology 
of the vulnerability of the children included in the Type 4 are the vulnerability of children which is low and lower child welfare with a percentage of 74.3 percent. The problems that occur in children are regarded as something that can be addressed by the child but the child may not feel the happiness on herself. There is 25.7 percent of children included in Type 1 is the child vulnerability low but child welfare high. In this case the children tend to be able to solve the problems on the child so that the child is able to feel the happiness and satisfaction on herself.

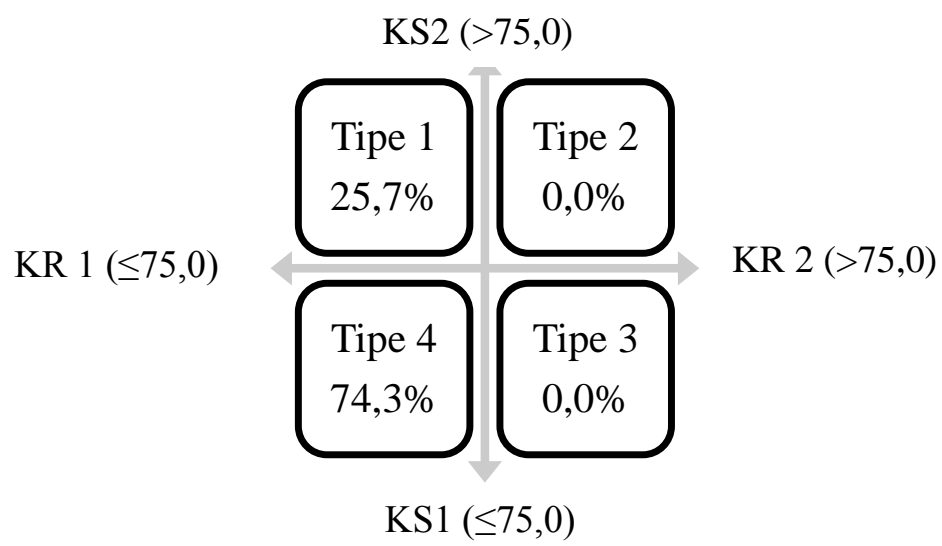

Information:

KR $1=$ Low Vulnerability $(\leq 75,0 ;$ score $0-100)$

KR 2 = High Vulnerability $(>75.0$; score $0-100)$

KS $1=$ Low Welfare $(\leq 75,0 ;$ score $0-100)$

KS $2=$ High Welfare $(>75.0$; score $0-100)$

Figure 1 The typology distribution of children vulnerability and child welfare

\section{The Relationship between Family Characteristics, Children Characteristics and Children Vulnerability and Children Welfare}

The correlation test between family size with child welfare is negatively significant (Table 4). That is, the greater the number of family members, the lower welfare the child would be. According Muflikhati et al. (2010), families with the larger number of family members tend to be inprosperous in comparison to the number of less family members. Then the child's birth order is correlated negatively significant with child welfare. That is, the greater child's birth order, the lower the child's welfare, and vice versa the smaller the birth order of the child, higher the child's welfare. Hurlock (1980) stated that children, adolescents and adults who are from various positions on birth order indicate that birth order can be a factor in determining personal and social adjustment by the individual throughout his life. Meanwhile, the age of the father and mother did not correlated negatively significant with child welfare. That is the higher or the older of a father and mother, the less welfare of the children. 
Table 4 Pearson correlation coefficient of family and children characteristics with the children vulnerability and child welfare

\begin{tabular}{|c|c|c|}
\hline \multirow[b]{2}{*}{ Variables } & \multicolumn{2}{|c|}{ Pearson Correlation } \\
\hline & $\begin{array}{c}\text { Children } \\
\text { Vulnerability }\end{array}$ & Subjective Child Welfare \\
\hline \multicolumn{3}{|l|}{ Family Characteristic } \\
\hline Father Age (years) & 0,079 & $-0,277$ \\
\hline Mother Age (years) & 0,093 & $-0,295$ \\
\hline Length of father education (years) & 0,240 & 0,275 \\
\hline Length of mother education (years) & 0,112 & 0,060 \\
\hline Family Size (person) & $-0,088$ & $-\mathbf{0 , 3 3 8 *}$ \\
\hline Family Income (per capita) & 0,095 & $-0,015$ \\
\hline \multicolumn{3}{|l|}{ Child characteristics } \\
\hline Children Age (years) & $-0,157$ & 0,048 \\
\hline Children Birth Order (to-) & $-0,126$ & $-0,385 *$ \\
\hline $\begin{array}{l}\text { Children Internal Vulnerability (score 0- } \\
100 \text { ) }\end{array}$ & - & 0,223 \\
\hline Children Welfare (score 0-100) & 0,223 & - \\
\hline
\end{tabular}

Note: * significant on $\mathrm{p}$-value $<0.05$

According to Hurlock (1980) the higher of person's age, the more problems faced, so happiness is felt to be on the wane. Length of father and mother education is not significantly positively associated with child welfare. That is, the higher education of the father and mother, the higher the child welfare will be. Philips (2002) stated that children coming from parents who have higher educations will improve children quality and welfare compared to those coming from low education parents.

Then, the child's age did not significantly positively associated with child welfare. That is, the older the child, the higher the child welfare. According to Sixmith et al. (2007) well-being of children aged 8 to 12 years is achieved when the interpersonal relationships with family and friends (including pets), and the positive activities or things to do goes according to developmental stages.

The results in Table 4 above also show that the family and the child characteristics variable do not have a significant relationship with the children's vulnerability. This is consistent with research by De Ocampo et al. (2003), which states that there is no relationship between the demographics of parents (father and mother's education, father and mother's age, and socioeconomic status) with the vulnerability of children. Age of the father and mother, father and mother long education related to family income and the child's age but not significantly positively associated with children's vulnerability. That is, the older the mother, the father and the children's vulnerability is increasing.

\section{DISCUSSION}

This study uses the theory of structural-functional approach. Functional structural assume that each family is a system consisting of subsystems that are interconnected and become one entity (Megawangi, 2014). Structural-functional theory approach can be used to analyze the role of family members in order to function properly to maintain the integrity of the family and society (Newman \& Grauerholz, 2002). One important aspect of the structural-functional perspective 
is that every family is physically and mentally healthy. In other words, there is division of tasks or roles which are obvious family functions, these functions are arranged in a hierarchical structure that is harmonious, and their commitment to the implementation of the role or function. Family structure in this study is a complete family consisting of father, mother, and child. The father is the head of the family as well as the main breadwinner, all kinds of work that fathers did in this study were farmers, and a small portion mother helped earn a living extras such as farming also trades and most of the wife of an obligation fully to his family, while the children fulfill their obligation to assist the work.

Both parents were helping with household tasks and in terms of farming as well as the right to study and they were given love affection and protection of their parents. Based on the characteristics of the family can be said that farming families are relatively more traditional. This is evident from the large number of family members in a family of farmers so that farming families included in this type of extended family, the husband role as the main breadwinner and the wife's role as a housewife, workplace and living quarters are relatively close together, and the child according to the parents and wife very obedient to her husband. There is a family of poor farmers in meeting the economic needs of the family as well as the lack of care for children's basic needs such as physical and psychosocial health that can lead to turmoil in the family of one vulnerability in children.

Family means respondents in this study who had a meaning that the family is the place to share the ups and downs, a build a future together, the pride of every member of the family, the fun, happiness and able to guide the family to be able to live better. Based on family meaning, it can be concluded that farming families in this study still considers that the family is as very important and precious. Cultural background is one factor of the importance of a family. Families in this study generally have Sundanese cultural background that has characteristics of the people gentle, smooth words, friendly, adhering to the faith and piety, mutual respect, and mutual respect. Family farmers in this study belong to the morfostatic system - the system which maintaines stability and have restrictions on caregivers from outside and give negative feedback. Families with these systems tend to be closed (closed system), which is more concerned with the internal exchange of the exchange outside the system, such as using the labor of their own family members than on the help of others (Deacon \& Firebaugh 1988).

According to respondents, child is a child that is everything for the parents, the parents have high expectations of the children whose parents want their children to be responsible, to educate their children to high school, to be successful for the nation and the state, to success in education, employment and a child's future. Based on the meaning of the child to the family, we can conclude that the family had good expectations for their children. Son of farmers in this study belong to the category with lower children's vulnerability and lower child welfare or included in Type 4. That is the child who is able to overcome the existing problems in the child but the child is still not yet feel the happiness and satisfaction of the child's life. Although fathers and mothers have low education and father's occupation as a farmer, but parents can still provide protection and their affection towards their children. This is not in line with Anthony et al. (2003) 
which states that the low parental education will increase the vulnerability of children. This is in contrast with the results for the average family of rural communities such as farmers, especially the traditional family is generally low education level. But the farmers whose education is low education levels, parents can still spend a lot of time for their kids. Time is one component of investment for children (Bryant \& Zink, 2006). The work of farmers who do not all day in the garden can make parents feel free for children who tend to be more. Give parents free time for children is the time to engage in parenting. Good parenting of parents will make children can grow and develop properly. This can reduce children's vulnerability to the physical and psychological child because the parents, especially the mother to control the situation of children with physical or mental child. Moreover, it can be seen that a family function in the family farmer to run well, this is in line with the Thompson et al. (2007) which states that a family function to improve the mental health of children, so that children can overcome the problems that exist in the child's own.

Limitations in this study is the vulnerability of children and the welfare of children which can be only seen by the viewpoints and perceptions of children and mothers, not based on the statements of all family members. This research is a new look at the vulnerability of children in the emotional and social dimensions, while other dimensions have not been included, as well as the welfare of children only see from a psychological dimension, economic and social. So that the overall results have not shown. Characteristic examples in this research is also less diverse. Statement role in the questionnaire used is still not specific or too general so that they can not see the factors that affect the welfare of children.

Conceptually the welfare of the child depends on the role of parents and the community. Therefore, improving the quality of parents in parenting and child protection to meet the needs of children The need for socialization, motivation and education of government against children to continue their education until the minimum rank of first mengah schools and parents can encourage their children to attend school. The need for implantation noble values or characters in children through education in schools, so that children can be a good person in the future.

\section{CONCLUSIONS AND RECOMMENDATION}

\section{Conclusions}

Internal vulnerability of farm families of children showed that children of farmers are relatively low. This indicates that the child is able to overcome the problems in children such as emotional and social. External vulnerabilities family children indicate that children of farmers are in a lower category. This suggests that the children of farmers are not in a social environment that makes children have vulnerable families and surrounding communities. Subjective well-being of children in a family of farmers showed that the children of farmers are relatively low. This shows that the children cannot feel happiness and satisfaction in him.

Typology of vulnerability of children and the welfare of children, including the children's vulnerability Type 4 is low and well-being of children is low. This shows that even though the child farmers have been able to overcome the 
problems that exist on the emotional and social development, but children may not feel the happiness and satisfaction on her. But there are families that belong to Type 1 - vulnerability of children low and child welfare high. None of the farmers' children is currently on the type of vulnerability of children and the welfare of children is in Type 2 and Type 3.

The greater the number of family members and the greater the child's birth order, the less subjective the well-being of children. There is no significant relationship between family variables and children with children's vulnerability. The results also showed that the higher vulnerability of children, the subjective well-being of children will be low, and vice versa, but the relationship between the two is not significant.

\section{Recommendation}

From the results of the study, it can be suggestted that first, the need for child protection on the vulnerability of children and improving the welfare of children by the government or the education, social services, and services related to child protection. This is to support the contents of the Act No23 of 2002 on the protection of children and the Law No. 4 of 1979 on child welfare. Secondly, the need for socialization, education or empowerment, and assistance to families in regards to family planning programs in order to improve the welfare of children. Third, the population in this study has the characteristic of a homogeneous sample, so that the site selection in future studies is expected to have the characteristics of different examples, e.g. highland and lowland farmers.

\section{REFERENCE}

Andrews, G., Skinner, D., Zume, K. (2006). Epidemiology of health and vulnerability among children orphaned and made vulnerable by HIV/AIDS in sub-Saharan Africa. AIDS Care: Psychological and Socio-medical Aspects of AIDS/HIV. 18(3): 269-276

Anshor, M.U., Ghalib, A. (2010). Parenting With Love. Bandung (ID): Mizania

Anthony, K.K., Gil, K.M., Schanberg, L.E. (2003). Brief report: Parental perceptions of child vulnerability in children with chronnic illness. Journal of Pediatric Psychology. 28(3):185-190

Bannet, H.P. (2012). The white paper for vulnerable child Volume I [Internet]. [Diunduh 2014 juli 24]. Tersedia pada: http://www.msd.govt.nz/documents/about-msd-and-our-work/workprogrammes/policy-development/white-paper-vulnerable-children/whitepaper-for-vulnerable-children-volume-1.pdf

Bryant, W.K., Zink, C.D. (2006). The Economic Organization of the Household, Second Edition. New York (US): Cambridge Univ Pr.

Bruskas, D. (2008). Children in foster care: a vulnerable population at risk. Journal of Child and Adolescent Psychiatric Nurshing. 21(2):70-77

Cutter, S.L., Boruff, B.J., Shirley, W.L. (2003). Social vulnerability to environmental hazards. Social Science Quarterly. 84(2):242-261. 
Daniel, B. (2010). Concepts of adversity, risk, vulnerability and resilience: a discussion in the context of the 'child protection system'. Social Policy \& Society. 9(2):231-241

De Ocampo, A.C., Macias, M.M, Saylor, C.F, Kartikaneni, L.D. (2003). Caretaker perception of child vulnerability predicts behavior problems in nicu graduates. Child Psychiatry and Human Development. 34(2): 83-96

Deacon. R., Firebaugh, F. (1988). Family Resource Management: Principles and Applications, 2nd Edition. Boston: Allyn and Bacon, Inc.

De Duncan, A.F., Caughy, M.O. (2009). Parenting style and the vulnerable child syndrome. Journal of Child and Adolescent Psychiatric Nurshing. 22(4):228-234

Ehring, T., Caffier, B.T., Gross, J.J., Schnulle, J., Fischer, S. (2010). Emotion regulation and vulnerability to depression: spontaneous versus instructed use of emotion suppression and reappraisal. American Psychological Association. 10(4):563-572.

Engle, P.L., Castle, S., Menon, P. (1996). Child development: vulnerability and resilience [Internet]. [Diunduh 2014 Oktober 23]. Tersedia pada: http://ageconsearch.umn.edu/bitstream/97309/2/child\%20development.pdf

Farhood, L.F. (2004). The impact of low stress on the health of Lebanese families. Research an Theory for Nursing Practice: An International Journal. 18(2/3).

Fernandes, L., Mendes, A., Teixeira, A.A.C. (2010). A review essay on child well-being measurment: uncovering the paths for future research. FEP Working Papers [Internet]. [Downloaded 2014 February 20]. Tersedia pada: www. Fep.up.pt/investigacao/workingpapers/ 10.12.20_wp 396. pdf

Firdaus, (2008). The relationship between economic pressure, financial management, and coping mechanisms with family welfare women tea pickers [Underganduate thesis]. Bogor (ID): Bogor Agricultural Institute

Forsyth, B.W.C., Horwitz, S.M., Leventhal, J.M., Burger, J., Leaf, P.J. (1996). The child vulnerability scale: an instrument to measure parental perceptions of child vulnerability. Journal of Pediatric Psychology. 21(1):89-101.

Guralnick, M.J. (1998). Effectiveness of early intervention for vulnerable children: a developmental perspective. American Journal on Mental Retardation. 102(4):319-345

Gustiana, W.D. (2012). Parental perceptions about secondary education and expenditure allocation to education in a family of farmers in Bogor [thesis]. Bogor (ID): Bogor Agricultural University.

Hastuti, D. (2009). Parenting : Theory and Principles and Its Application in Indonesia. Bogor (ID): Institut Pertanian Bogor

Hartayo, Aniri, N.B. (2010). Analysis of level of family welfare fidh farmers and non fish farmers Bogor. Journal of Family and Consumer Sciences. 3 (1): 64-73

Hurlock, E.B. (1980). Developmental Psychology. 5th ed. Jakarta (ID): Erlangga.

Ihromi, T.O. (2004). Anthology, sociology of the family. Ihromi TO, editor. Jakarta: Book Torch.

Institute for Human Services for the Ohio Child Welfare Trainning Program. (2011). Assessing Child Vulnerabilities [Internet]. [Downloaded 2014 July $18]$ Available

at: 
http://www.ocwtp.net/PDFs/CAPMIS/D.\%20Child\%20Vulnerabilities\%2 0Reading.pdf

Iskandar, Hartoyo, Sumarwan, U, Khomsan, A. (2010). Factors that affect of family welfare. Journal of Community Nutrition, Department Community Nutrition, Faculty of Human Ecology, Bogor Agricultural University, Bogor. 10 (2): 133-141

Krikpatrick, S.M., Rojjanasrirat, W., South, B.J., Sindt, J.A, Williams, L.A. (2012). assessment of emotional status of orphans and vulnerable children in Zambia. Journal of Nurshing Scholarship. 44(2): 194-201

Kumpulainen, S. (2006). Vulnerability Concepts in Hazard and Risk Assessment. Geological Survey of Finland, Special Paper. 42:65-75

Lippman, L.H. (2007). Indicators and indicies of child well-being: a brief American history. Social Indicators Research. 83:39-53

Marliana, S. (2012). Suicide as a conscious choice individual: critical analysis of philosophical concepts against suicide Emile Durkheim. [Thesis]. Depok (ID): Faculty of Humanities, Philosophy Studies Program, University of Indonesia.

Mealli, F., Pudney, S., Rosati, F. (2006). Measuring the economic vulnerability of children in developing countries. An application to Guatemala [Internet]. [Diunduh 2013 Desember 03]. Tersedia pada: https://www.iser.essex.ac.uk/files/iser_working_papers/2006-28.pdf

Megawangi, R. 2014). Allowing different; new perspective on gender relations. Jakarta (ID): mizan.

Moore, K.,A., Theokas, C., Lippman, L., Bloch, M., Vandivere, S., O'hare, W. (2008). A microdata child well-being index: conceptualization, creation, and findings. Child Indicators Research. 1: 17-50

Muflikhati, I. Hartoyo, Sumarwan, U., Fahrudin, A., Puspitawati, H. (2010). The socio-economic conditions and the level of family welfare: the case in coastal areas of West Java. Journal of Family and Consumer Sciences. 3 (1) .1-10.

Muriuki, A.M., Moss, T. (2016). The impact of professional social workers and community health care workers in Côte d'Ivoire: Contributions to the rotection and social support of vulnerable children in a resource poor country. Children and Youth Services Review. 67: 230-237

Nadiya, A. (2013). The relationship between family welfare with children welfare in farm families. [thesis]. Bogor (ID): Bogor Agricultural University.

Newman, D.M., Grauerholz, L. (2002). Sociology of families. Thousand Oaks, CA: Pine Forge Press.

Permana, R. (2008). West Java disaster reduction center studies: disaster relief equal to tackle poverty [Internet]. [Downloaded 2014 December 17]. Available at: http://wjdrsc.wordpress.com/2008/04/20/mengatasi-bencana$\underline{\text { mengatasi-kemiskinan/ }}$

Peterson, T.L., Chatters, L.M., Taylor, R.J., Nguyen, A.W. (2014). Subjective well-being of older African Americans with DSM IV psychiatric disorders. Journal of Happiness Studies. 15(5): 1179-1196 
Philips, K.R. (2002). Parent work and child well being in low income families, urban institute [Internet]. [Downloaded 2014 November 30]. Available pada: http://www.urban.org/uploadedpdf/acf3d39.pdf

Pollard, E.L., Lee, P.D. (2003). Child well-being: a systematic review of the literature. Social Indicators Research. 61(1):59-78

Purdy, I.B. (2004). Vulnerable: a concept analysis. Nurshing Forum. 39(4): 25-33

Puspitawati, H. (2012a). The role of gender, women's economic contribution and family welfare horticultural farmers. [thesis]. Bogor (ID): Bogor Agricultural Values.

Press.

, (2013). Introduction to the study of the family. Bogor: IPB

Raphael, B., Stevens, G., Pedersen, K. (2006). Vulnerability and mental health. Vulnerability and youth studies: an international interdisciplinary. Journal for Research, Policy and Care. 1(2): 127-138, doi: 10.1080/17450120600863380

Simanjuntak M. (2010a). Factors that affect family welfare and learning achievement of children in Receiver of Hope Family Program. [thesis]. Bogor (ID): Bogor Agricultural University.

, (2010b). Demographic characteristics, social and family economics in receiver of hope family program (PKH). Journal of Family and Consumer Sciences. 3 (2): 101-113

Sixmith, J., Gabhainn, S.,N., Fleming, C., O'Higgins, S. (2007). Childrens', parents', and teachers' perceptions of child wellbeing. Health Education. 107(6): 511-523

Skinner, D., Tsheko, N., Munyati, S.,M., Segwabe, M., Chibatamoto, P., Chandiwana, S.,M.,B., Nkoma, N., Tlou, S., Chitiyo, G. (2004). Defining Orphaned and Vulnerable Children [Internet]. [Diunduh 2014 Februari 17].

Tersedia pada:https://www.k4health.org/sites/default/files/Defining\%20Orphaned\% 20and $\% 20$ Vulnerable $\% 20$ Children $\% 20 \% 20$ Defining\%20Orphaned $\% 20$ an d\%20Vulnerable\%20Children\%20-\%20Entire\%20eBook.pdf

Sprinthall, N.A, Sprinthall, R.C, (1990). Educational Psychology: A Developmental approach ed.5. New York: Mc. Grawhill.

Statham, J., Chase, E. (2010). Childhood wellbeing: A brief overview [Internet]. [Downloaded 2014 April 13]. Available at: https://www.gov.uk/government/uploads/system/uploads/attachment_data/ file/183197/Child-Wellbeing-Brief.pdf

Sumarwan, U. (2002). Consumer behavior: theory and practice in marketing. Bogor (ID): Ghalia Indonesia.

Sunarti, E. (2004). Parenting by Heart. Jakarta (ID): PT. Elex Media Komputindo .(2009). Vulnerability indicators of farmers and fishermen family for disaster risk reduction in agriculture [Internet]. [Downloaded 2014 April 20]; Available

at: http://repository.ipb.ac.id/bitstream/handle/123456789/53266/Indikator\%2 OKerentanan.pdf? sequence $=1$

The National Family Planning Board. (1996). Opinion prosperous family development. Jakarta (ID): The National Family Planning Board 
The Central Statistics Agency. (1996). Indicator of children and youth welfare 1996. Jakarta (ID): BPS

(2013). Poor people and poverty line 1970-2013

[Internet]. [Downloaded 2014 December 04]. Available at: http://www.bps.go.id/tab_sub/view.php?kat=1\&tabel=1\&daftar=1\&id_su byek $=23 \&$ notab $=7$

data. Jakarta (ID): BPS

(2014). Monthly report on socio-economic

(2016). Percentage of poor people by province, 2013-2016 [Internet]. [Accessed 2016 December 05]. Available at: https://www.bps.go.id/linkTableDinamis/view/id/1219

(2016). Characteristics of poor households and non-poor households in 2013 and 2014 [Internet]. [Accessed 2016 December 05]. Available at: https://www.bps.go.id/linkTableDinamis/view/id/908

Suyanto, B. (2010). Social Problem Child: Revised Edition. Jakarta: Prenada Media Group

Tembong, G.P. (2006). Smart Parenting. Jakarta (ID): PT. Alex Media Komputindo

The Ministry of Education and Culture. Invite Mendikbud Post. (2013). Open to Students Reduce Dropout [Internet]. [Accessed 2014 November 26]. Jakarta (ID). Available at: http://kemdikbud.go.id/kemdikbud/node/1037

The President's Emergency Plan for AIDS Relief, OGAC. (2006). Orphans and Other Vulnerable Children Programming Guidance for United States Government In-Country Staff and Implementing Partners [Internet]. [Diunduh 2014 februari 14]. Tersedia pada: http://www.pepfar.gov/documents/organization/83298.pdf

Thomasgard, M., Metz, W.P. (1999). Parent-child relationship disorders: What do the child vulnerability scale and the parent protection scale measure? Clinical Pediatrics. 38(6): 347-354

Thompson, R., Lindsey, M.A., English, D.J., Hawley, K.M., Lambert, S., Browne, D. (2007). The influence of family environment on mental health need and service use among vulnerable children. Child Welfare. 86(5): 57-74

Torrico, R. (2009. From poverty to child welfare involment: the critical role of housing in family stability [Internet]. [Di unduh 2014 Desember 6 ]. Tersedia pada: http://www.socialworkers.org/practice/children/2009/sept2009.pdf

UNICEF. (2011). Children and climate change: children's vu;nerability to climate change and disaster impacts in East Asia and the Pacific [Internet]. [Diunduh 2014 Desember 05]. Tersedia pada: http://www.unicef.org/media/files/Climate_Change_Regional_Report_14_ Nov_final.pdf17]. Tersedia pada: http://www.unicef.org/indonesia/id/media_21386.html , (2012). Summary of child protection studies [Internet]. [Downloaded 2014 September 24]. Available at: http://www.unicef.org/indonesia/id/A7 B_Ringkasan_Kajian_Perlindung an.pdf 
, (2013). Conference on the child poverty and social protection brought new hope to the indonesian children [Internet]. [Downloaded 2014 December 17]. Available at: http://www.unicef.org/indonesia/id/media_21386.html

Woolfolk, A.E, (2004), Educational Psychology 9th ed. United State of America: Mc. Grawhill

Wong, F.K.D., Chang, Y.L, He, X.S. (2009). Correlates of psychological wellbeing of children of migrant workers in Shanghai, China. Social Psychiat Epidemiol. 44:815-824.

Yanti, L. (2013). Analysis of factors affecting demand of life insurance in makassar. [thesis]. Makassar (ID): Department of Economics, Faculty of Economics and Business, University of Hasanuddin.

Yuda, D.C.K. (2012). Causes of children out of school and abatement method. [thesis]. Malang (ID): Department of Special Education School, State University of Malang

Zambrana, R.E., Dorrington, C. (1998). Economic and social vulnerability of latino children and families by subgroup: implications for child welfare. Child Welfare League of America. 82(1):5-27. 